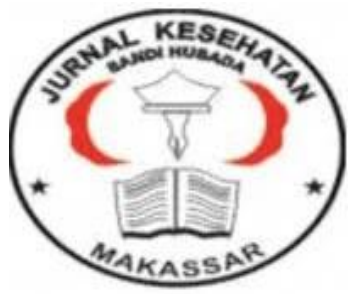

\author{
Jurnal Ilmiah Kesehatan Sandi Husada \\ hhttps://akper-sandikarsa.e-journal.id/JIKSH \\ Volume 9, Nomor 2, Desember 2020, pp 916-921 \\ p-ISSN: 2354-6093 dan e-ISSN: 2654-4563 \\ DOI: $10.35816 /$ jiskh.v10i2.432
}

\title{
Obstructive Sleep Apnea (OSA) dan Hubungannya dengan Defisiensi Vitamin D
}

Obstructive Sleep Apnea (OSA) and Its Association with Vitamin D Deficiency

\begin{tabular}{l}
\multicolumn{1}{c}{ Artikel info } \\
\hline \hline \\
Artikel history: \\
Received; Juli 2020 \\
Revised: Agustus 2020 \\
Accepted; September 2020
\end{tabular}

Dandy Fahsi Algifary

Fakultas Kedokteran, Universitas Lampung

\begin{abstract}
.
It is estimated that as much as $2-4 \%$ of the total middle-aged population suffer from sleep apnea, with a trend towards men compared to women. The long-term effects of Obstructive Sleep Apnea (OSA) include impaired cognitive function, insulin resistance, cardiovascular disease, and depression. Research on the relationship between vitamin D and OSA severity has become an important concern because vitamin $D$ deficiency is also a common medical problem worldwide, and its prevalence is increasing along with obesity, sedentary lifestyles, limited sun exposure, and aging. The aim of this literature study was to determine the relationship between OSA and the presence of Vitamin D deficiency. Methods. This research is a literature review involving 18 libraries from 2 national journals and 16 international journals. Result. Various studies have shown an association between vitamin $D$ deficiency and OSA caused by complex pathogenetic mechanisms and influenced by several confounding factors. It found that patients with severe OSA were associated with vitamin $D$ deficiency. Conclusions. In the OSA patients evaluated as having vitamin $D$ deficiency, it was generally associated with severe OSA.
\end{abstract}

\begin{abstract}
Abstrack.
Diperkirakan sebanyak 2-4\% dari total populasi paruh baya menderita apnea tidur, dengan kecenderungan pada pria dibandingkan dengan wanita. Efek jangka panjang Obstructive Sleep Apnea (OSA) antara lain gangguan fungsi kognitif, resistensi insulin, penyakit kardiovaskular, dan depresi. Penelitian mengenai hubungan antara vitamin $D$ dan keparahan OSA telah menjadi perhatian penting karena kekurangan vitamin $D$ juga menjadi masalah medis yang umum di seluruh dunia, dan prevalensinya meningkat seiring dengan obesitas, gaya hidup yang tidak banyak bergerak, paparan sinar matahari yang terbatas, dan penuaan. Tujuan dari studi literatur ini adalah untuk mengetahui hubungan
\end{abstract}


antara OSA dan dengan adanya defisiensi Vitamin D. Metode. Penelitian ini merupakan literature review dengan melibatkan 18 pustaka yang berasal dari 2 jurnal nasional dan 16 jurnal internasional. Hasil. Berbagai penelitian menunjukkan adanya hubungan antara defisiensi vitamin D dan OSA yang disebabkan oleh mekanisme patogenetik yang kompleks dan dipengaruhi oleh beberapa faktor perancu. Ditemukan pasien dengan OSA yang parah berkaitan dengan kekurangan vitamin D. Kesimpulan. Pada pasien OSA yang dievaluasi memiliki kekurangan vitamin $D$, secara umum berkaitan dengan OSA yang parah.

Keywords:

Apnea-hypopnea index;

Obstructive Sleep Apnoea;

Vitamin D;
Coresponden author:

Email: dandyalgi09@gmail.com

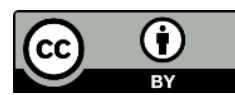

artikel dengan akses terbuka dibawah lisensi CC BY -4.0

\section{Pendahuluan}

Obstructive sleep apnea (OSA) adalah suatu kondisi yang ditandai dengan episode berulang dari kolapsnya jalan napas bagian atas atau seluruhnya selama tidur yang mengakibatkan penghentian total (apnea) atau pengurangan (hipopnea) aliran udara yang menyebabkan bangun dari tidur dan hipoksia (Gharibeh \& Mehra, 2010). OSA juga dapat didefinisikan sebagai episode berulang dari oklusi saluran napas bagian atas (parsial atau lengkap) yang menyebabkan hipoksemia arteri berulang dan fragmentasi tidur (Archontogeorgis et al., 2016). Kondisi ini terjadi pada sekitar $4 \%$ pria paruh baya dan $2 \%$ pada wanita (Hukins, 2006). OSA juga merupakan masalah kesehatan umum pada anak-anak, yang mempengaruhi hingga 3-4\% dari semua anak. Anak-anak ras Afrika Amerika dan obesitas memiliki prevalensi OSA yang lebih tinggi (Kheirandish-Gozal et al., 2014).

Patogenesis OSAS masih belum jelas dan mungkin multifaktor, termasuk berbagai mekanisme seperti inflamasi dan stres oksidatif (Archontogeorgis et al., 2016). Diperlukan pemeriksaan subyektif untuk menegakkan diagnosis OSA berdasarkan gejala klinis dan obyektif dengan alat diagnostik. Perangkat diagnostik yang sederhana adalah Epworth Sleepiness Scale (ESS) yang berupa kuisoner yang diisi oleh pasien sendiri. Keuntungan dari ESS adalah cepat, tidak mahal dan reabilitas tinggi namun korelasi ESS dengan derajat OSA masih rendah (Kadarullah \& Annisa, 2016). Polisomnografi (PSG) adalah metode standar emas untuk diagnosis dan penilaian derajat keparahan OSA (Gharibeh \& Mehra, 2010). Penilaian PSG dilakukan dan dianalisis sesuai dengan kriteria standar American Academy of SleepMedicine (AASM). Indeks apnea-hipopnea (AHI) yaitu jumlah rata-rata apnea ditambah hipopnea yang diekspresikan per jam tidur, digunakan untuk diagnosis OSA dan penilaian tingkat keparahannya. OSA diklasifikasikan sebagai ringan jika $5 \leq \mathrm{AHI}$ $<15$, sedang jika $15 \leq \mathrm{AHI}<30$, dan berat jika $\mathrm{AHI} \geq 30$ per jam (Bouloukaki et al., 2020).

Pasien biasanya mengeluh mengantuk di siang hari, kelelahan, kurang konsentrasi dan bangun dengan sensasi tersedak atau nyeri jantung. Anggota keluarga dapat melihat pasien dengan OSA mendengkur dan sesak napas saat tidur. Insiden gangguan ini dapat meningkat karena peningkatan obesitas dan penuaan populasi. Efek jangka panjang OSA antara lain gangguan fungsi kognitif, resistensi insulin, penyakit kardiovaskular, dan depresi. Hal ini berkontribusi pada peningkatan morbiditas, mortalitas dan peningkatan biaya kesehatan (Bromińska et al., 2017).

Vitamin D adalah vitamin yang larut dalam lemak dan terbagi dalam dua bentuk yaitu ergocalciferol (vitamin D2) yang diperoleh melalui sumber makanan (makanan alami, 
makanan yang diperkaya, dan suplemen) serta cholecalciferol (vitamin D3) yang terutama diproduksi di kulit setelah terpapar radiasi matahari. Paparan sinar matahari adalah sumber utama vitamin D bagi kebanyakan orang. Bentuk vitamin D2 dan D3 dianggap tidak aktif secara biologis hingga mengalami reaksi hidroksilasi enzimatik di hati, menghasilkan pembentukan 25-hidroksivitamin D (25 (OH) D) yang merupakan bentuk sirkulasi utama vitamin D. $25(\mathrm{OH})$ D kemudian mengalami hidroksilasi di ginjal di bawah pengaruh enzim $1 \alpha$-hidroksilase untuk menghasilkan bentuk vitamin $D$, kalsitriol atau $1,25(\mathrm{OH})$ 2D yang aktif secara biologis dan dihidroksilasi (Archontogeorgis et al., 2016). Serum $25(\mathrm{OH})$ D direkomendasikan sebagai penanda pilihan untuk evaluasi status vitamin D (Kueider et al., 2016). Kekurangan vitamin D dikaitkan dengan kadar serum 25 $(\mathrm{OH}) \mathrm{D}$ di bawah $20 \mathrm{ng} / \mathrm{mL}$. Kekurangan vitamin D merupakan masalah medis umum di seluruh dunia, dan prevalensinya meningkat seiring dengan obesitas, gaya hidup yang tidak banyak bergerak, paparan sinar matahari yang terbatas, dan penuaan (Siachpazidou et al., 2020)

Penelitian mengenai hubungan antara vitamin D dan keparahan OSA telah menjadi perhatian penting tetapi hasilnya masih kontroversial. Beberapa meta-analisis telah melaporkan bahwa pasien dengan OSA memiliki kadar vitamin D yang lebih rendah daripada pasien sehat (Neighbors et al., 2018; Ma et al., 2020) dan lainnya menunjukkan bahwa kekurangan vitamin D lebih sering terjadi pada mereka dengan OSA yang parah (Kerley et al., 2016; Ma et al., 2020). Oleh karena itu, tujuan dari literature review ini adalah untuk mengetahui keterkaitan antara defisiensi vitamin D pada pasien OSA sehingga dapat memberikan informasi yang bermanfaat bagi masyarakat.

\section{Metode}

Penelitian ini menggunakan studi literature review, dengan peneliti yang berperan mencari dan menggabungkan inti sari serta menganalisis fakta dari sumber ilmiah yang sesuai kriteria valid dan akurat. Studi literatur menyajikan kembali materi yang diterbitkan sebelumnya, dan melaporkan fakta atau analisis baru. Tinjauan literature menyajikan ringkasan berupa publikasi paling relevan kemudian membandingkan hasil yang disajikan dalam makalah. Penelusuran sumber pustaka dalam artikel ini melalui database PubMed dan Google Scholar. Sumber pustaka yang digunakan dalam penyusunan melibatkan 18 pustaka yang terdiri dari 2 jurnal nasional dan 16 jurnal internasional. Pemilihan artikel sumber pustaka dilakukan dengan melakukan peninjauan pada judul, abstrak dan hasil yang membahas tentang hubungan defisiensi vitamin D dengan OSA. Hasil studi literatur ini berupa publikasi yang relevan.

\section{Hasil Dan Pembahasan}

Dalam penelitian yang dilakukan oleh Goswami et al. (2016) mengenai keterkaitan konsentrasi $25(\mathrm{OH})$ D yang lebih rendah dengan prevalensi yang lebih besar dan peningkatan keparahan OSA, kelompok kontrol dibagi menjadi empat kelompok (pasien non-OSA, pasien dengan OSAS derajat ringan, sedang dan berat). Hasilnya didapatkan bahwa subjek dalam kuartil $25(\mathrm{OH}) \mathrm{D}$ terendah berada pada peningkatan risiko apnea tidur parah dibandingkan dengan subjek di kuartil $25(\mathrm{OH})$ D tertinggi. Indeks Massa Tubuh (IMT) dan lingkar leher menjadi prediktor independen dari rendahnya kadar serum 25 (OH) D di OSAS. (Goswami et al., 2016).

Penelitian lain oleh Mete et al. (2013) dengan 150 pasien OSA (50 pasien dengan OSA derajat ringan, 50 dengan OSA derajat sedang, dan 50 dengan OSA derajat berat) yang didiagnosis dengan PSG, dibandingkan dengan kelompok kontrol sebanyak 32 pasien nonOSA. Tidak didapatkan perbedaan yang signifikan secara statistik pada kadar serum 25 
$(\mathrm{OH})$ D antara OSA dan kontrol ( $\mathrm{p}>0,05)$. Namun, dalam analisis subkelompok OSAS, didapatkan bahwa pasien dengan OSA parah memiliki kadar $25(\mathrm{OH})$ D yang secara signifikan lebih rendah dibandingkan dengan kelompok lain $(p=0,003)$. Juga didapatkan jumlah pasien dengan defisiensi serum $25(\mathrm{OH}) \mathrm{D}(<10 \mu \mathrm{g} / \mathrm{dl})$ lebih tinggi pada kelompok OSA dibandingkan pada kelompok kontrol $(\mathrm{p}<0,05)$. Sehingga didapatkan kesimpulan ketika keparahan OSAS meningkat, defisiensi $25(\mathrm{OH})$ D menjadi lebih jelas ((Mete et al., 2013).)

Bozkurt et al. (2012) membandingkan kadar vitamin D serum antara kontrol sehat dan pasien OSA dengan peningkatan keparahan. Konsentrasi serum $25(\mathrm{OH}) \mathrm{D}$ pasien OSA $(17,4 \pm 6,9 \mathrm{ng} / \mathrm{mL})$ lebih rendah daripada pada subjek kontrol $(19,9 \pm 7,8 \mathrm{ng} / \mathrm{mL})$ dan penurunannya menjadi lebih jelas dengan peningkatan keparahan OSAS ( $p=0.097)$. Selain itu, pasien dengan OSA berat menunjukkan kadar $25(\mathrm{OH}) \mathrm{D}$ serum $(16,31 \pm 6,98 \mathrm{ng} / \mathrm{mL})$ yang secara signifikan lebih rendah dibandingkan dengan kontrol $(19,93 \pm 7,81 \mathrm{ng} / \mathrm{mL})$ dengan nilai $\mathrm{p}<0,05$ (Bozkurt et al.,2012).

Pada penelitian yang dilakukan oleh Barcelo et al.(2013) dengan kelompok kontrol pasien OSA derajat ringan, sedang dan berat didapatkan kadar serum $25(\mathrm{OH})$ D lebih rendah pada OSA derajat berat $(27.2 \pm 15.6 \mathrm{ng} / \mathrm{ml})$ dibandingkan dengan OSA derajat ringan sampai sedang $(30.7 \pm 14.2 \mathrm{ng} / \mathrm{ml})(p=0,006)$. Peningkatan kadar $25(\mathrm{OH}) \mathrm{D}$ juga dapat menurunkan risiko diabetes $(\mathrm{p}=0,038)$ dan sindrom metabolik $(p<0,001)$ ( Barcelo et al., 2012). Selain itu, studi kadar vitamin D dan OSA pada anak-anak oleh Kheirandish-Gozal et al. (2015) menunjukkan bahwa anak-anak obesitas dan anak-anak dengan OSA ditemukan kadar plasma $25(\mathrm{OH})$ D yang jauh lebih rendah jika dibandingkan dengan kontrol yang sehat. Jika obesitas dan OSA terjadi secara bersamaan, kadar $25(\mathrm{OH}) \mathrm{D}$ juga akan semakin berkurang ( $p, 0,001)$ (Kheirandish-Gozal et al., 2014).

Patogenesis kekurangan vitamin D di OSA bersifat multifaktorial dan belum sepenuhnya dipahami. Kadar vitamin D serum yang rendah dapat berkontribusi pada pengembangan OSA melalui beberapa mekanisme. Reseptor vitamin D yang terletak di otot rangka, memodulasi beberapa faktor transkripsi dalam sel otot, dan terlibat dalam proliferasi dan diferensiasi sel otot menjadi serat otot tipe II dewasa. Selain itu, vitamin D bertanggung jawab untuk transportasi kalsium aktif ke retikulum sarkoplasma, sehingga mengatur kontraksi otot sarkomerik. Adanya defisiensi vitamin D juga berhubungan dengan kejadian miopati proksimal. Pada pasien yang menerima terapi statin, ditemukan kadar vitamin D yang rendah yang menimbulkan peningkatan kejadian miopati. Ada kemungkinan bahwa peningkatan kadar hormon paratiroid, hipofosfatemia dan penurunan kadar kalsitriol, yang menyertai defisiensi vitamin D, dapat menyebabkan kelemahan otot Dengan demikian, kekuatan otot dilator faring berkurang pada defisiensi vitamin D sehingga memungkinkan patensi faring dan predisposisi kejadian apnoea selama tidur (Archontogeorgis et al., 2016).

Namun belum ada penelitian yang mengevaluasi efek terapi penggantian vitamin $D$ terhadap kekuatan otot dilator faring. Hasil dari tinjauan sistematis dari 16 randomised controlled trials (RCT) oleh Rejnmark (2011), efek pengobatan dengan vitamin D pada fungsi otot mendukung efek menguntungkan dari suplementasi vitamin D pada kekuatan dan fungsi otot pada orang tua. Dari sejumlah besar penelitian yang ditinjau, gagal untuk mengkonfirmasi efek tersebut, dan ada kekurangan data tentang kemungkinan efek pada orang dewasa yang lebih muda. Selain itu, vitamin D menghambat sekresi sel T-helper pro inflamasi (Th) 1 sitokin (interleukin (IL) -2 , interferon- $\gamma$ dan tumor necrosis factor (TNF) a) dan meningkatkan produksi anti-inflamasi Th2 sitokin (IL-3, IL-4, IL-5 dan IL-10) Keadaan inflamasi memainkan peran penting dalam perkembangan penyakit kardiovaskular pada pasien dengan OSA (Rejnmark, 2011). 
Goswami, 2016 et al. (2016) juga mengaitkan konsentrasi 25 (OH) D yang rendah dengan fungsi muskuloskeletal yang buruk. Kontrol tonus otot saluran napas bagian atas dianggap sebagai kontributor utama OSA, dan oleh karena itu pasien dengan konsentrasi $25(\mathrm{OH}) \mathrm{D}$ yang rendah mungkin memiliki peningkatan risiko OSA karena fungsi otot rangka yang lebih buruk yang mendukung patensi saluran napas bagian atas selama tidur. Konsentrasi $25(\mathrm{OH}) \mathrm{D}$ yang rendah juga dikaitkan dengan peradangan saluran napas, rinitis kronis, dan infeksi saluran napas atas yang berulang, yang menyebabkan pembesaran tonsil (610), yang juga dapat berkontribusi pada insiden dan keparahan OSA. Konsentrasi $25(\mathrm{OH})$ D yang rendah juga berhubungan dengan diabetes melitus tipe 2 , sindrom metabolik, dan obesitas, yang kesemuanya sering ditemukan pada pasien dengan OSA (Goswami et al., 2016).

Penjelasan lain tentang hubungan antara OSA dan vitamin D adalah bahwa OSA dikaitkan dengan rasa kantuk yang berlebihan pada siang hari. Pasien OSA yang melaporkan rasa kantuk yang berlebihan di siang hari cenderung memiliki akses yang terbatas ke aktivitas luar ruangan yang akhirnya mengurangi paparan sinar matahari sehingga menurunkan sintesis vitamin D. Bouloukaki et al. (2020) juga menjelaskan bahwa kadar vitamin D yang terus-menerus rendah dikaitkan dengan miopati, hipertrofi tonsil, dan rinitis, yang berpotensi menjadi predisposisi perkembangan OSA dan kantuk di siang hari (Bouloukaki et al., 2020).)

\section{Simpulan Dan Saran}

Hubungan antara defisiensi vitamin D dan OSA disebabkan oleh mekanisme patogenetik yang kompleks dan dipengaruhi oleh beberapa faktor perancu. Fakta bahwa kekurangan vitamin D tampaknya umum di antara pasien OSA menunjukkan bahwa skrining harus dilakukan jika ada indikasi klinis. Dari berbagai penelitian ditemukan bahwa pasien OSA yang dievaluasi memiliki kekurangan vitamin D, yang secara umum berkaitan dengan OSA yang parah. Penelitian lebih lanjut juga diperlukan untuk menilai efek suplementasi vitamin D pada keparahan OSA. Penelitian lebih lanjut dengan penyesuaian yang tepat dengan faktor perancu juga diperlukan untuk dapat menjelaskan lebih lengkap hubungan dan mekanisme kekurangan vitamin D pada OSAS dan kebutuhan suplementasi.

\section{Daftar Rujukan}

Archontogeorgis, K., Nena, E., Papanas, N., \& Steiropoulos, P. (2018). The role of vitamin D in obstructive sleep apnoea syndrome. Breathe, 14(3), 206-215. https://doi.org/10.1183/20734735.000618

Aziza, D. O., \& Kurniati, K. I. (2019). Suplementasi Vitamin D pada Wanita dengan Polycystic Ovarian Syndrome (PCOS) Vitamin D Supplementation in Women with Polycystic Ovarian Syndrome (PCOS). Jiksh, 10(2), 169-177. https://doi.org/10.35816/jiskh.v10i2.140

Barceló, A., Esquinas, C., Piérola, J., De La Peña, M., Sánchez-De-La-Torre, M., Montserrat, J. M., Marín, J. M., Duran, J., Arqué, M., Bauça, J. M., \& Barbé, F. (2013). Vitamin d status and parathyroid hormone levels in patients with obstructive sleep apnea. Respiration, 86(4), 295-301. https://doi.org/10.1159/000342748

Bouloukaki, I., Tsiligianni, I., Mermigkis, C., Bonsignore, M. R., Markakis, M., Pataka, A., Steiropoulos, P., Ermidou, C., Alexaki, I., Tzanakis, N., \& Schiza, S. (2020). Vitamin D deficiency in patients evaluated for obstructive sleep apnea: is it associated with disease severity? Sleep and Breathing. https://doi.org/10.1007/s11325-020-02142$\mathrm{w}$

Bozkurt, N. C., Cakal, E., Sahin, M., Ozkaya, E. C., Firat, H., \& Delibasi, T. (2012). The relation 
of serum 25-hydroxyvitamin-D levels with severity of obstructive sleep apnea and glucose metabolism abnormalities. Endocrine, 41(3), 518-525.

https://doi.org/10.1007/s12020-012-9595-1

Bromińska, B., Ruchała, M., Cyrańska-Chyrek, E., Kuźnar-Kamińska, B., Kostrzewska, M., \& Batura-Gabryel, H. (2017). State of the art paper Obstructive sleep apnea and hormones - a novel insight. Arch Med Sci, 13(4), 875-884. https://doi.org/10.5114/aoms.2016.61499

Gharibeh, T., \& Mehra, R. (2010). Obstructive sleep apnea syndrome: Natural history, diagnosis, and emerging treatment options. Nature and Science of Sleep, 2, 233-255. https://doi.org/10.2147/NSS.S6844

Goswami, U., Ensrud, K. E., Paudel, M. L., Redline, S., Schernhammer, E. S., Shikany, J. M., Stone, K. L., \& Kunisaki, K. M. (2016). Vitamin D concentrations and obstructive sleep apnea in a multicenter cohort of older males. Annals of the American Thoracic Society, 13(5), 712-718. https://doi.org/10.1513/AnnalsATS.201507-4400C

Hukins, C. A. (2006). Obstructive sleep apnea - Management update. Neuropsychiatric Disease and Treatment, 2(3), 309-326. https://doi.org/10.2147/nedt.2006.2.3.309

Kadarullah, O., \& Annisa, Y. (2016). Pengaruh Obstructive Sleep Apnea ( OSA) Terhadap Terjadinya. XIII(2), 11-21.

Kerley, C. P., Hutchinson, K., Bolger, K., McGowan, A., Faul, J., \& Cormican, L. (2016). Serum Vitamin D is significantly inversely associated with disease severity in Caucasian adults with obstructive sleep apnea syndrome. Sleep, 39(2), 293-300. https://doi.org/10.5665/sleep.5430

Kheirandish-Gozal, L., Peris, E., \& Gozal, D. (2014). Vitamin D levels and obstructive sleep apnoea in children. Sleep Medicine, 15(4), 459-463. https://doi.org/10.1016/j.sleep.2013.12.009

Kueider, A. M., Tanaka, T., An, Y., Kitner-Triolo, M. H., Palchamy, E., Ferrucci, L., \& Thambisetty, M. (2016). State- and trait-dependent associations of vitamin-D with brain function during aging. Neurobiology of Aging, 39, 38-45. https://doi.org/10.1016/j.neurobiolaging.2015.11.002

Ma, D., Zheng, X., Dong, L., Zheng, C., Chen, Y., Chen, Z., Lin, M., Li, X., Li, Z., \& Liu, C. (2020). The relationship of serum 25-hydroxyvitamin-d level with severity of obstructive sleep apnea in patients with type 2 diabetes mellitus. Diabetes, Metabolic Syndrome and Obesity: Targets and Therapy, 13, 1391-1398. https://doi.org/10.2147/DMSO.S250694

Mete, T., Yalcin, Y., Berker, D., Ciftci, B., Guven, S. F., Topaloglu, O., Yavuz, H. C., \& Guler, S. (2013). Obstructive sleep apnea syndrome and its association with vitamin D deficiency. Journal of Endocrinological Investigation, 36(9), 681-685. https://doi.org/10.3275/8923

Neighbors, C. L. P., Noller, M. W., Song, S. A., Zaghi, S., Neighbors, J., Feldman, D., Kushida, C. A., \& Camacho, M. (2018). Vitamin D and obstructive sleep apnea: a systematic review and meta-analysis. Sleep Medicine, 43, 100-108. https://doi.org/10.1016/j.sleep.2017.10.016

Rejnmark, L. (2011). Effects of vitamin D on muscle function and performance: A review of evidence from randomized controlled trials. Therapeutic Advances in Chronic Disease, 2(1), 25-37. https://doi.org/10.1177/2040622310381934

Siachpazidou, D. I., Kotsiou, O. S., Stavrou, V., Pastaka, C., Gogou, E., Kechagia, M., Varsamas, C., Economou, N. T., Zouridis, S., Patrikioy, E., Seitanidis, G., Pinaka, M., Sistou, A., Hatzoglou, C., \& Gourgoulianis, K. I. (2020). Serum vitamin D levels in patients with obstructive sleep apnea syndrome and level changes after continuous positive airway pressure therapy. Sleep and Breathing. https://doi.org/10.1007/s11325020-02146-6 